\title{
PENDIDIKAN BAGI ANAK DI LEMBAGA PEMASYARAKATAN KHUSUS ANAK KELAS IIA JAKARTA
}

\author{
Firman Assiddiqi \\ Surel: firmanassiddiqi60@gmal.com
}

\begin{abstract}
In the implementation of education for children organized by the Special Correctional Institution of class II A Jakarta, children have learned or educated education, formal, informal, and informally. In this study the approach used by the authors is a qualitative approach, wherein in this research the author does how a series of interviews, observations and literature research to acquire data, in this research author Also uses a descriptive research method in which to describe the existing problems of education for children. At A grade II children's prison in Jakarta, education is not only based on formal education, other education is also held as well as non-formal and informal education. This informal education in the form of education is pursuing a package for those correctional students who have not completed their education by the time they have not been caught by the case of criminal acts, informal education provided to the child by the officer is Spiritual education and skills. As for the barriers to the education process, there are two barriers that are internal barriers posed from within each child and external obstacles caused by outside factors such as officers and environment.
\end{abstract}

Keywords: Education, Children, Correctional Special for Children

\begin{abstract}
ABSTRAK
Pada pelaksanaan pendidikan bagi anak yang diselenggarakan oleh Lembaga Pemasyarakatan Khusus Anak kelas II A Jakarta, anak telah mendapatkan pembelajaran atau pendidikan baik pendidikan, formal, nonformal, dan informal. Dalam penelitian ini pendekatan yang digunakan oleh penulis adalah pendekatan kualitatif, dimana dalam penelitian ini penulis melakukan berapa rangkaian wawancara, observasi dan penelitian kepustakaan untuk memperoleh data, dalam penelitian ini penulis juga menggunakan metode penelitian deskriptif di mana bertujuan untuk mendeskripsikan permasalahan yang ada yaitu pendidikan bagi anak. Pada Lapas Khusus Anak kelas II A Jakarta, pendidikan dilakukan tidak hanya bertumpu pada pendidikan formal, pendidikan yang lainnya juga diselenggarakan seperti halnya pendidikan nonformal dan informal. Pendidikan nonformal ini berupa pendidikan kejar paket untuk mereka para Anak Didik Pemasyarakatan yang belum menyelesaikan pendidikannya pada saat mereka belum terjerat kasus tindak pidana, pendidikan informal yang diberikan kepada anak oleh petugas adalah pendidikan kerohanian dan keterampilan. Adapun hambatan untuk proses pendidikan, terdapat dua hambatan yaitu hambatan internal yang ditimbulkan dari dalam diri masing-masing anak dan hambatan eksternal yang disebabkan oleh faktor luar seperti petugas dan lingkungan.
\end{abstract}

Kata kunci : Pendidikan, Anak, Lembaga Pemasyrakatan Khusus Anak 


\section{PENDAHULUAN}

Undang-Undang Dasar 1945 pada pasal 31 (1) menjalaskan bahwasanya setiap warga negara Indonesia memiliki hak dan kesempatan yang sama dalah hal memperoleh pendidikan selama mereka masih dalam usia pendidikan.

Dijelaskan kembali pada ayat (3) bahwa sistem pendidikan yang ada harus diusahakan oleh pemerintah untuk memenuhi kesempatan pendidikan bagi peserta didik, sehingga tidsk ada perbedaan antara peserta didik dalam memperoleh pendidikan. Demikian juga dijelaskan pada pasal 5 ayat 1 Undang-Undang Nomor 20 tahun 2003 warganegara Indonesia memeiliki hak yang sama dalam memperoleh atau mengenyam pendidikan yang bermutu tidak ada perbedaan antar mereka. Sehingga dijelaskan kembali, Anak D (Kahesti, 2018) Didik Pemasyarakatan seharusnya mendapatkan hak-hak nya sebagaimana status yang dimiliki sebagai seorang anak termasuk hak untuk memperoleh pendidikan yang sama.

Banyak kasus di Indonesia dimana anak yang berurusan dengan hokum mendapat perlakuan yang tidak sesuai dengan peraturan atau UndangUndang yang telah dijelaskan diatas, dimana anak tersebut dikeluarkan dari sekolahnya tanpa ada pembelaan dari anak yang bersangkutan ketika anak bermaslah dnegan hukum. Tindakan ini jelas telah melanggar azas praduga tak bersalah, hal ini terjadi karena pihak sekolah tidak paham dengan azas hukum tersebut. Namun hal ini sangat memprihatinkan dimana seharusnya sekolah sebagai sarana mencerdaskan anak bangsa untuk disiapkan di kemudiah hari, dan melaksanakan pendiidkan yang dicanangkan oleh pemerintah,tidak semena-mena mengeluarkan anak dari sekolah karena mereka sedang berhadapan dengan hukum.

Pada umumnya masyarakat awam tidak mengetahui adanya pendidikan untuk Anak Didik Pemasyarakatan di dalam Lembaga Pemasyarakatan. Mereka beranggapan bahwa setiap orang yang masuk Lembaga Pemasyarakatan adalah orang jahat yang bermasalah dengan hukum. Demikian pula dengan anakanak yang telah keluar dari Lembaga Pemasyarakatan akan mendapat lebelling oleh masyarakat dan hanya akan menjadi orang yang tidak berguna didalam lingkungan tempat tinggal mereka, anak akan dikucilkan dan mereka akan cenderung berdiam diri.

Kemudian bagaimana agar dapat membuat pemahaman yang dianggap oleh masyarakat awam bahwa orang-orang yang masuk dalam Lembaga Pemasyarakatan itu ketika keluar dapat berguna dan bahkan bisa lebih baik dari sebelum dia masuk di Lembaga Pemasvarakatan. Hal inilah yang harus dicermati sistem pelaksanaan pendidikan bagi Anak Didik Pemasyarakatan agar mereka ketika kembali berintegrasi sosial kedalam lingkungan masyarakat mampu disejajarkan diri dan diterima oleh anak-anak sebayanya sebagai mana mestinya anak yang tidak pernah 
berhadapan dnegan hukum, mengikuti pendidikan formal di sekolah-sekolah di luar Lembaga Pemasyarakatan.

Jika mmebahas tentang pola pelaksanaan sistem pendidikan bagi anak, tanpa membahas faktor yang menjadi persoalan dalam pelaksanaannya yang dinilai masih banyak yang belum optimal. Salah satu faktor penyebab belum optimalnya pendidikan di Lembaga Pemasyarakatan adalah kurangnya minat dari Anak Didik Pemasyarakatan itu sendiri mengenai pendidikan yang diberikan oleh pihak Lembag Pemasyarakatan. Akan tetapi tidak semua Anak Didik Pemasyarakatan seperti itu, namun hal inilah yang dapat mempengaruhi Anak Didik Pemasyarakatan yang lainnya untuk tidak mengikuti pendidikan yang diberikan oleh pihak Lembaga Pemasyarakatan. Oleh karena itu perhatian dari segala aspek tentang persoalan pemenuhan hak pendidikan bagi anak yang ada di dalam LPKA sangat amat diperlukan, hal ini bertujan melancarkan hambatan pemberian hak pendidikan sama halnya dengan pemenuhak Hak Asasi Manusia terhadap anak tersebut.

Hal ini menunjukkan bahwa untuk mendukung terciptanya proses pembinaan yang baik dan efektif pada Anak Didik Pemasyarakatan, yang bertujuan untuk menjadikan anak yang bermutu dan dapat berguna bagi bangsa dan negara dikemudian hari, maka mereka seharusnya dikumpulkan dan dikelompokkan sesuai dengan status mereka, sehingga konsep pembinaan itu sendiri dapat dijadikan bekal yang sangat berarti terhadap perkembangan mereka dikemudian hari, dan tidak melakukan pelanggaran hukum, karena pendidikan sudah terpenuhi dan dapat melanjutkan pendidikan pendidikan ketika sudah bebas dan kembali ke masyarakat.

Dalam penelitian ini manfaat yang diharapkan untuk diperoleh adalah peneliti memberikan kontribusi dalam pengembangan ilmu Pemasyarakatan. Diharapkan dapat menjadi sumbang saran dan pemikiran akan peranan pentingnya pendidikan bagi anak yang bermaslah dengan hukum agar mereka mendapat hak yang sama dengan anak seusianya di luar sana, dan juga mereka tidak merasa dikucilkan ketika kelak akan keluar dari Lembaga Pemasyarakatan dan kembali ke masyarakat seutuhnya, dan dapat melangsungkan hidupnya secara normal.

\section{METODE PENELITIAN}

Pendekatan kualitatif dipilih oleh peneliti dalam peroses penelitian ini, dimana pendekatan kualitatif adalah suatu cara penelitian dengan serangkaian wawancara yang disajikan didalam penelitian. Alasan menggunakan pendekatan kualitatif karena penelitian ini cocok bagi peneliti untuk melakukan proses penyelidikan dalam bidang maslah sosial dan kemanusian bagi anak dalam haknya memperoleh pendidikan yang layak dan bermutu. Dimana peneliti melakukan pemahaman tentang makna dari suatu kejadian yang diletiti, melaporkan ulasan dari 
narasumber untuk kemudian dikaji dan kemudian disusun dalam sebuah latar ilmiah. Lexy J Moleong menyatakan dalam penggunaan metode kualitatif terdapat beberapa pertimbangan yang harus diperhatikan. Ia menyatakan: Hal pertama yang harus diperhatikan dalam metode ini adalah bukti-bukti nyata yang didapat dari lapangan baik dari pelaku maupun orang disekitar pelaku,yang kedua peneliti harus berinteraksi langsung dengan pelaku atau sumber data. Hal yang harus diperhatika yang ketiga adalah kemungkinan peneliti untuk melakukan pengembangan data ang diperoleh dari lapangan sesuai dengan pemahaman dan pemaknaan yang ada. (Lexy J Moleong, 2014 :11). Pendidikan bagi anak di Lembaga Pemasyarakatan merupakan hal yang khusus dalam penelitian ini, karena penelitian ini meneliti masalah pendidikan bagi anak di Lembaga Pemasyrakatan dan hal yang terkait didalamnya.

Peneliti menggunakan metode penelitian deskriptif dimana metode ini bertujuan untuk mendeskripsikan masalah yang coba diangkat dan dicari faktor penghambat dan pendukung dalam penelitian pendidikan bagi anak. Untuk mendukung penulisan Artikel ini, penulis menggunakan sumbersumber bacaan melalui buku dan peraturan yang berkaitan dengan permasalahan yang ada, yaitu pendidikan bagi anak di Lembaga Pemasyarakayn Khusus Anak, yang diangkat oleh peneliti serta penelusuran melalui internet yang berkaitan dengan hak memperoleh pendidikan studi kepustakaan.

Data yang didapat dari hasil penelitian baik data yang berupa data primer maupun data sekunder, oleh peneliti akan dilakukan analisis menggunakan cara kualitatif dan selanjutnya data akan disajikan menggunakan metode deskriptif, yaitu menjelaskan data, menguraikan masalah, dan yang terakhir menggambarkan peermasalahan yang ada dalam penelitian ini. Selain dilakukan analisa peneliti juga melakukan transkip percakapan informan dengan peneliti saat peneliti melakukan wawancara

Data yang diperoleh oleh peneliti saat melakukan penelitian, akan dilakukan pengkajian terlebih dahulu, langkah selanjutnya yaitu data dipadukan dengan bahan pustaka yang berkaitan dengan penelitian yang dilakukan serta dipadukan juga dengan peraturan perundang-undangan yang melandasi data tersebut atau yang menaungi permaslaahan yang diteliti. Kemudian mncari dan menemukan relevansi antara data yang didapatkan oleh peneliti dengan landasan teori dan peraturan perundang-undangan yang berlaku.

\section{HASIL PENELITIAN DAN PEMBAHASAN}

Anak yang sedang menjalani masa pidana di Lembaga Pemasyrakatan, juga memiliki hak yang sama dalam memperoleh pendidikan, anak yang ada didalam, dapat diberikan pendidikan berupa pendidikan formal baik SD, SMP, dan 
SMA yang diberlangsungkan di dalam kelas, dan juga pendidikan nonformal dan informal. KASI BIDADIK Lapas Khusus Anak Kelas IIA Jakarta mengatakan bahwa selain pendiikan formal, anak yang berada didalam juga mendapat pendidikan nonformal dan informal, yang bertujuan untuk membekali anak berupa ketrampilan dan kemandirian untuk dapat diterima kembali kelak ketika sudah bebas. Ketiga pendidikan ini sangat penting sebagai bekal untuk mereka menjalani hidup secara normal di masyarakat dan tidak kembali mengulangi kesalahannya lagi. (Bhayangkara \& Raya, 2018).

Pendidikan Formal bagi anak yang berada didalam LAPAS dimulai dari Tingkat Sekolah Dasar (SD) Berdasarkan hasil wawancara dengan KASI BINADIK Lembaga Pemasyrakatan Khusus Anak Kelas II A Jakarta menyatakan ada ruangan khusu yang disediakan oleh pihak LAPAS untuk anak yang melakukan pendidikan khususnya sekolah dasar, yaitu SD, terdapat guru dan fasilitas penunjang lainnya untuk kelancaran peroses belajar mengajar bagi anak yang ada di dalam LAPAS. Pelaksanaan pendidikan SD semuanya dibiayai oleh Pemerintah Daerah (PEMDA) sehingga SD mendapatkan bantuan operasional Bantuan Operasional Sekolah (BOS). Pendidikan SD ini diikuti oleh 38 orang Anak Didik Pemasyarakatan. Pendidikan formal yang selanjutnya adalah Sekolah Menengah Pertama (SMP) KASI BINADIK pada Lembaga Pemasyrakata Khusus Anak
Kelas II A Jakarta juga menyampaikan bahwa pada awalnya, pihak Lembaga Pemasyrakata Khusus Anak Kelas II A Jakarta memiliki beberapa hambatan dalam dalam peroses pemberian hak kepada anak didalam Lapas, khususnya hak memperoleh pendidikan, terkhusus bagi mereka yang dalam program pendidikan tingkat menengah atau SMP yaitu masalah saran dan prasarana.Nmaun mereka meiliki solusi yaitu dengn bekerjasama dengan SMP yang ada disekitar Lapas untuk tetpa memberikan pendidikan kepada ada yang seddang menjalani hukuman didalam Lapas.

Program yang diberikan kepada anak tidak hanya pendidikan formal saja sebagaimana yang diberikan oleh guru di sekolah pada umumnya. Anak juga memperoleh pendidikan informal berupa keterampilan, dan kecakpan membuat karya. Untuk ruangan dibedakan dengan sekolah dasar yang bertujan untuk tidak ada saling ketergangguan antara sekolah dasar dan sekolah menengah dalam menempuh pendidikan, mereka akan berjalan beriringan karena kelas yang digunakan juga berbeda. Pendidikan SMP ini juga diikuti oleh Anak Didik Pemasyarakatan sebanyak 19 orang.

Demikian pula pada tingkat SMA, KASI BINADIK juga menyampaikan bahwa pihak nya tidak dapat memberikan pendidikan formal kepada anak pada tingkat SMA sebagaimana mestinya yang diterima anak anak yang ada diluar sana, karena mengingat ruangan, tenaga pengajar 
maka pihak Lapas hanya memberikan fasilitas berupa ijazah penyetaraan bagi mereka yang ingin mengikuti atau mengejar ujian paket $\mathrm{C}$, pihak lapas akan memberi ijin dan fasilitas bagi anak yang mau mengikuti ujin tersebut.

Selain pendidikan formal anak juga diberikan pendidikan nonformal, pendidikan nonformal diberikan secara berjenjang dan terstruktur sesuai bakat dan minat anak. Pendidikan non formal diberikan kepada anak yang bertujuan untuk memberikan bekal baik keterampilan dan bakad sesuai dengan minat anak, yang akan menunjang pendidikan formal ketika kelak anak sudah bebas dari Lapas. Adapun macam-macam pendidikan formal antara lain berupa pendidikan kecakapan, pendidikan keterampilan, pendidikan latihan kerja, pendidikan sosial, pendidikan kesetaraan serta beberapa pendidikan yang dapat menunjang kemampuan anak didik di dalam maupun ketika nanti anak bebas. Tidak berhenti disitu anak juga diberi sebuah kursus atau pelatihan untuk menunjang kemampuan mereka, kegiatan ini diselenggarakan bagi anak yang ingin mengasah keterampilan dan kecakapan dalam mengembangkan diri, serta mengembangkan profesi bekerja. Tidak kalah dari pendidikan formal pendidikan non formal juga akan diberikan sertifikat ataupun tanda kecakapan yang yang dikeluarkan oleh pihak Lapas ataupun pihak ketiga yang bekerjasama dalam bidang ini dengan lapas. Semua itu akan dipertanggungjawabkan kepada pemerintah pusat Direktorat Jenderal
Pemasyarakatan, pemerintah daerah yaitu kanwil Kementerian Hukum dan hak asasi manusia.

Pendidikan kerohanian salah satu pendidikan yang didapat oleh anak di lembaga Pemasyarakatan khusus anak kelas IIA jakarta yang merupakan unsur program pendidikan informal. Pendidikan rohanian dianggap penting bagi anak sehingga petugas memberikan pendidikan ini karena anak yang telah berurusan dengan hukum dan dimasukkan ke Lembaga Pemasyarakatan tersebut dianggap kurang dalam pemenuhan kebutuhan kerohaninya. Pendidikan yang berupa pendidikan rohanian penting diberikan oleh pihak petugas LAPAS kepada anak karena pendidikan ini sebagai dasar terbentuknya anak tersebut, jika kerohanian dari seorang anak sudah baik maka tingkah laku atau perilaku dari anak tersebut akan baik juga, dan begitu juga sebaliknya. Pendidikan etika juga diberikan terhadap anak oleh petugas Lapas. Contohnya pada saat makan pagi dan makan siang, semua Anak Didik Pemasyarakatan dikeluarkan dari kamarnya masingmasing dan semua berbaris rapi di lapangan apel guna melaksanakan apel makan pagi dan apel makan siang. Tidak sampai disitu saja, setelah apel makan, mereka langsung masuk ke dalam ruangan makan dimana mereka semua dikumpulkan menjadi satu untuk makan bersama- sama dimulai dengan berdoa sebelum makan. Pemandangan yang sangat jarang sekali terlihat di dalam sebuah Lapas yang berada di Indonesia saat ini. Hal 
tersebut rutin dilakukan karena untuk mendidik etika, moral, dan disiplin mereka.

Ada beberapa faktor penghambat dalam pelaksanaan pendidikan bagi anak di Lapas khusu anak, pembagian faktor tersebut dibagi menjadi dua, yang pertama adalah faktor internal dan faktor penghambat eksternal. Dalam faktor internal menjelaskan bawah anak anak yang sulit menjalankan pendidikan di LAPAS disebabkan oleh faktor dari dalam diri anak tersebut, mereka tidak memiliki minat dan keinginan untuk melaksanakan pendidikan formal informal, maupun non formal. Tidak berhenti di situ faktor pengajar atau guru berpengaruh dalam proses pendidikan ini karena pada kenyataannya tenaga pengajar yang intensif masuk untuk mengajar hanya pada guru SD, sedangkan bagi guruguru SMP tidak terlalu intensif dalam hal pengajaran yang dilakukan terhadap anak lingkungan lembaga Pemasyarakatan. Beberapa hal diatas yang menyebabkan keterlambatan anak dalam menempuh pendidikan khususnya pendidikan tingkat SMP, dan juga jam pengajar yang dinilai sangaat sedikit dalam peroses belajar mengajar berpengaruh dalam keterlambatan tersebut,hal ini berbading terbalik dibandingkan dengan jam pengajaran di sekolah dasar atau SD.

Pemberian pebellling kepada anak yang berurusan dengan hukum dan dimasukkan ke dalam Lembaga Pemasyarakatan Khusus Anak sangat ditatakuti oleh anak itu sendiri, pasalnya pemberian lebelling ini akan menimbulakan jarak antara anak sebagai penerima hak dalam Lapas dengan petugas yang bertindak selaku pemberi hak untuk anak. Menurut data yang ada, LAPAS Khusus Anak Kelas IIA Jakarta sudah memenuhi persyaratan untuk dikatagorikan sebagai LAPAS layak untuk anak, baik dari segi sarana maupun prasarana. Pada kenyataan yang ada lebelling masih sangat melekat pada anak pelanggar hukum, dan ini merukapakan faktor penghambat untuk peroses belajar mengajar bagi anak, stigma jelek selalu diberikan kepada anak yang berapada di dalam Lembaga Pemasyarakatan, meskipun anak sudah mematuhi segala peraturan dan tata tertib yang berlaku, tidak melakukan pelanggaran dan mengikuti semua intruksi dari petugas yang ada.

Hambatan yang selanjutnya adalah hambatan eksternal, hambatan ini ditemui pada peroses pemberian hak pendidikan kepada anak di Lembaga Pemasyarakatan Khusus anak. Kurangnya perhatian pihak pemerintah baik peerintah pusat maupun pemerintah daerah merupakan salah satu faktor penghambat eksternal yang terjadi di Lapas Anak sebagian besar dibeberapa wilayah di Indonesia,tidak luput di LAPAS Khusus Anak Jakarta. Tidak berhenti hanya dalam program pendidikan, efek stress petugas akan menyebabkan timbulnya kesalahpahaman antara petugas dan anak didik baik dalam segi pendidikan ,maupun dalam segi pembinaan lainnya.Perselisahan 
paham akan berakibat kurang maksimalnya program pembinaan yang diberikan oleh petugas kepada anak, hal ini merupakan efek berkepanjangn masalah dari tidak diberikannya tenaga konselor kepada anak dan petugas yang ada.

Bagi anak yang melaksanakan pendidikan pada usia SMA pendidikan formal tidak diberikan secara seutuhnya, karena anak didik hanya diberi kesempatan mengikuti ujian paket C. Hambatan selanjutnya yaitu ketika anak tidak sama sekali Mengikuti pendidikan formal ketika anak didik berada di luar Lapas, maka anak didik akan kesulitan dalam mengerjakan ujian paket C. Ini merupakan kelemahan dari petugas Pemasyarakatan yang tidak bisa ditangani sendiri oleh petugas, karena petugas hanya sebagai penyelenggara, hal ini merupakan buntut panjang kurangnya perhatian dari pemerintah pusat maupun pemerintah daerah. Pihak Lembaga Pemasyarakatan juga kurang dapat berkoordinasi dengan keluarga anak didik sehingga pendidikan baik formal, informal , maupun nonformal tidak sesuai dengan bakat dan minat anak itu sendiri, petugas cenderung hanya bertugas sebagai bentuk pengguguran kewajiban sebagai penyedia hak pendidikan bagi anak didik.

Adapun upaya yang dilakukan oleh petugas dalam mengatasi faktor penghambat dalam proses pemberian pendidikan kepada Anak Bermasalah dengan Hukum. Mencoba mencari tahu mengapa anak-anak malas untuk mengikuti pendidikan dengan cara membaurkan diri meskipun dengan sedikit pemaksaan demi kebaikan dan kemajuan si anak itu sendiri kelak. Menghapus stigma labelling yang dipakai oleh petugas terhadap Anak Didik Pemasyarakatan karena bagaimanapun juga hal tersebut sangat menggangu anak pada dasarnya dan membuat anak tertekan tidak berkembang dalam mengembangkan potensi yang ada pada dirinya khususnya di bidang pendidikan, hal tersebut hanya akan membuat anak semakin terpinggirkan di lingkungan masyarakat bila dia bebas nanti karena anak dibuat tidak percaya diri dan tidak mendapatkan pendidikan apaapa di dalam Lembaga Pemasyarakatan dan dapat dikhawatirkan akan kembali masuk ke dalam Lembaga Pemasyarakatan sebagai residivis.

Menambah jumlah konselor atau psikolog dianggap cara jitu dalam mengurangi faktor penghambat, karena selama ini Lembaga Pemasyarakatan tidak memiliki tenaga tersebut untuk mengatasi tingkat stres para petugas yang dapat berdampak pada pekerjaan mereka dalam menjaga Anak Didik Pemasyarakatan. Pemerintah seharusnya lebih melihat kedalam lagi mengenai pendidikan yang di selenggarakan oleh Lembaga Pemasyarakatan dan turut membantu dalam pelaksanaannya biar bagaimanapun pendidikan untuk anak adalah sepenuhnya tanggung jawab pemerintah.

Selain peran pemerintah, diperlukan juga peran orang tua atau keluarga untuk mengatasi dalam 
pelaksanaan program yang diberikan petugas di Lembaga Pemasyarakatan, salah satu contohnya melalui pemberian motivasi dari orang tua maupun keluarga mengenai pentngnya mengikuti aturan dan program yang ada, merupakan suatu hal yang sangat berguna. Kedudukan orang tua dalam pemberian motivasi terhadap yang berada anaknya memegang peran yang sangat strategis dimana anak di Lembaga Pemasyarakatan sangatlah membutuhkan motivasi dari orang tuanya. Motifasi dan semangat orang tua akan berdampat besar dalam peroses pemberian program pendidikan bagi anak, karena anak akan lebih semangat dan konsentrasi dalam mengikuti program ini.

\section{Pembahasan}

Berdasarkan pengamatan yang dilakukan penulis di Lembaga Pemasyarakatan Khusus Anak Jakarta, pihak petugas mengatakan masih saja ada anak yang malas atau tidak mau untuk mengikuti pendidikan di Lembaga Pemasyarakatan baik pendidikan formal, informal dan nonformal. Sekolah hanya sebagai syarat bahwa mereka pernah mendapatkan pendidikan tanpa mengerti akan pentingnya arti dari sekolah itu, akan tetapı mereka lebih menyukai ke arah pendidikan yang dalam artiannya bukan sekolah yakni pendidikan informal seperti marching band pramuka dan sebagainya, hanya saja untuk sekarang hal tersebut vakum untuk sementara. Seperti yang ditemukan di lapangan bahwa banyak Anak Didik Pemasyarakatan yang tidak mau dan malas untuk mengikuti pendidikan yang telah diadakan di Lembaga Pemasyarakatan tersebut, seharusnya mereka yang menjalani hukumannya di dalam Lembaga Pemasyarakatan bisa untuk lebih sadar akan pentingnya suatu pendidikan agar dapat diterima didalam lingkungan masyarakat apabila kita memiliki kepintaran intelektual setelah bebas nanti.

\section{SIMPULAN}

Berdasarkan uraian yang telah dikemukakan diatas (Undang-undang \& Anak, 2017) maka dapat disimpulkan Bahwa Lembaga Pemasyarakatan Kelas IIA Jakarta belum melaksanakan pendidikan bagi Anak Didik Pemasyarakatan secara optimal. Hal ini dikarenakan berbagai hambatan yang ada. Hambatan dalam peroses pemberian program pendidikan bagi anak di Lembaga Pemasyarakatan Khusus Anak Jakarta. Hambatan Internal Kurangnya minat belajar dari para Anak Didik Pemasyarakatan Labelling oleh petugas Lembaga Pemasyarakatan kepada setiap anak yang yang berurusan dengan hukum dan menjalani pembinaan di LAPAS khusu anak. Hambatan Eksternal dari prose pelaksanaan pendidikan yaitu kurangnya perhatian khusu yang diberikan oleh pemerintah pusat khusu Direktorat Jendral Pemasyarakatn terhadap keberadaan dan aktivitas yang dilakukan oleh etugas dalam melancarakan program pendidikn, kurangnya tenaga konselor atau psikolog pada Lembaga 
Pemasyarakatan Khusus Anak Kelas IIA Jakarta. Kurang koordinasinya antara pihak Lembaga Pemasyarakatan Khusus Anak Kelas IIA Jakarta kepada orang tua anak.

Solusi yang diberikan petugas dalam mengatasi masalah program pendidikan ini adalah, perlu adanya penekanan dan perhatian khusus terhadap kedisiplinan mengenai pendidikan belajar untuk Anak Didik Pemasyarakatan agar tumbuh keinginan dalam menjalani dan mengikuti pendidikan yang telah Lembaga Pemasyarakatan berikan. Menghapus stigma yang berkembang di kalangan petugas dengan cara memberikan pemahaman kepada petugas bahwa tidak semua Anak Didik Pemasyarakatan yang masuk ke dalam LAPAS khusus anak adalah penjahat. Kepala Lembaga Pemasyarakatan mengusulkan permintaan tenaga psikolog pada setiap penerimaan Pegawai di lingkungan Kanwil Kementerian Hukum dan HAM Jakarta. Kementrian Pendidikan dapat melakukan kerjasama dengan Lembaga Pemasyarakatan, dalam memfasilitasi hubungan orangtua, dan masyarakat untuk pengembalian anak dalam satuan masyarakat secara seutuhnya.

\section{DAFTAR RUJUKAN}

Bhayangkara, U., \& Raya, J. 2018. Pembinaan Khusus Anak Menurut Sistem Peradilan Pidana Anak. 1 (3), 215-230.

Biafri, S. 2019. Pembinaan Teroris
Anak Di Lembaga Pembinaan Khusus Anak Klas I Di Tangerang Child Terrorist Development in the Child Development Institution Class I in Tangerang. Sosio Konsepsia, 8(02), 14-26.

Chusniatun. 2018. Sistem Perlindungan Hukum Bagi Anak di Lembaga Pemasyarakatan Dalam Perspektif Konvensi Internasional Hak-Hak Anak. 30(01), 103-132.

Kahesti, Y. Z. 2018. Pemenuhan Hak Anak di Bidang Pendidikan pada Lembaga Pemasyarakatan Kelas IIA Kota Balikpapan. Jurnal Magister Hukum Udayana (Udayana Master Law Journal), 7(3), 343.

Undang-undang, A. D. D., \& Anak, P. 2017. Hak Pendidikan Bagi Narapidana Anak Ditinjau Dari Undang-Undang Nomor 35 Tahun $2014 \quad$ Tentang Perlindungan Anak. Lex Privatum, 5(1), 137-145. 